\title{
Vito Messina, Jafar Mehr Kian, “The Religious Complex at Shami. Preliminary Report on the Research of the Iranian-Italian Joint Expedition in Khuzestan at Kal-e Chendar"
}

\section{Rémy Boucharlat}

\section{(2) OpenEdition}

\section{Journals}

Édition électronique

URL : http://journals.openedition.org/abstractairanica/47081

DOI : 10.4000/abstractairanica.47081

ISBN : 1961-960X

ISSN : 1961-960X

Éditeur :

CNRS (UMR 7528 Mondes iraniens et indiens), Éditions de l'IFRI

\section{Référence électronique}

Rémy Boucharlat, «Vito Messina, Jafar Mehr Kian, "The Religious Complex at Shami. Preliminary Report on the Research of the Iranian-Italian Joint Expedition in Khuzestan at Kal-e Chendar" ", Abstracta Iranica [En ligne], Volume 37-38-39 | 2018, document 72, mis en ligne le 30 décembre 2018, consulté le 02 octobre 2020. URL : http://journals.openedition.org/abstractairanica/47081 ; DOI https://doi.org/10.4000/abstractairanica.47081

Ce document a été généré automatiquement le 2 octobre 2020.

Tous droits réservés 


\title{
Vito Messina, Jafar Mehr Kian, “The Religious Complex at Shami. Preliminary Report on the Research of the Iranian-Italian Joint Expedition in Khuzestan at Kal-e Chendar"
}

\author{
Rémy Boucharlat
}

\section{RÉFÉRENCE}

Vito Messina, Jafar Mehr Kian, "The Religious Complex at Shami. Preliminary Report on the Research of the Iranian-Italian Joint Expedition in Khuzestan at Kal-e Chendar" in Rolf A. Stucky, Oskar Kaelin, Hans-Peter Mathys (eds.). Proceedings of the 9th International Congress on the Archaeology of the Ancient Near East, June 9-13, 2014, University of Basel, vol. 3 Reports. Wiesbaden: Harrassowitz, 2016, p. 439-448.

1 La mission conjointe avait déjà réalisé la prospection du site et des environs en 2011 et 2012 (cf. dans ce numéro le cr Messina, Mehr Kian« Return to Shami... ») avant de commencer une série de sondages sur l'une des trois terrasses retenues par des murs de soutènement. Les constructions sont les unes en moellons non travaillés, d'autres autres en briques cuites carrées $(36 \times 36 \times 8 \mathrm{~cm})$. Une grande tombe $(4,5 \times 2,4 \mathrm{~m}$ et sans doute haute de $2 \mathrm{~m}$ ) construite en moellons possédait une couverture constituée de moellons disposes en double pente. Le sol et une banquette basse étaient également en dalles. 


\section{AUTEURS}

RÉMY BOUCHARLAT

UMR 5133 CNRS-Université de Lyon 